\title{
ПЕДАГОГИЧЕСКАЯ АНТРОПОЛОГИЯ
}

Вестник ПСТГУ.

Серия IV: Педагогика. Психология. 2017. Bun. 44. C. 67-83

\author{
Войтенко Татьяна Павловна, \\ канд. психол. наук, доцент, \\ зам. директора ГАОУ ДПО Калужской области \\ «Калужский государственный институт \\ развития образования» \\ 248600, Россия, Калуга, ул. Гагарина, 1 \\ TatianaVoyt@rambler.ru
}

\section{ПРИНЦИП СУБЪЕКТНОГО ПОДХОДА В ПСИХОЛОГИИ И ПЕДАГОГИКЕ: ПРОБЛЕМА АНТРОПОЛОГИЧЕСКОГО КОНТЕКСТА}

\author{
Т. П. ВОЙТЕНКО
}

\begin{abstract}
Статья посвящена обсуждению проблемы реализации принципа субъектного подхода и его непростой истории в науке. Причина сложившейся ситуации усматривается автором статьи в антропологической неопределенности исследований, связанных с понятием «субъект». Утверждается, что не всякий антропологический контекст понятия «субъект» является продуктивным: эволюционная концепция человека, на которую была вынуждена опираться вся отечественная наука советского периода, выступала серьезным препятствием исследований субъекта и субъектности. По мнению автора, огромный потенциал принципа субъектного подхода - ведущей методологической установки современной психологии и педагогики - может быть раскрыт только в контексте христианско-православной антропологии. В статье приводятся историографические и методологические обоснования данной точки зрения. Прослеживается история и предыстория принципа субъектного подхода, показывается диалектика понятия «субъект» в философской мысли. Автор систематизирует христианско-православные представления о человеке и, опираясь на них, дает определения понятиям «субъект», «субъектность» и «субъективность», а также раскрывает сущность принципа субъектного подхода. Отмечается высокая когерентность полученных дефиниций теоретическим построениям в области субъектной проблематики С. Л. Рубинштейна и В. И. Слободчикова.
\end{abstract}

Принцип субъектного подхода как ведущая методологическая установка современной психологии и педагогики

Субъектная проблематика занимает особое место в психологической науке и педагогической практике. Интерес ученых к этой исследовательской области обусловлен представлениями об активной, творческо-преобразующей роли человека в мире. Разработка данной проблематики связана с работами многих отечественных ученых: К. А. Абульхановой-Славской, Б. Г. Ананьева, А. В. Брушлинского, А. Л. Журавлева, В. В. Знакова, А. К. Осницкого, В. А. Петровского, С. Л. Рубинштейна, Е. А. Сергиенко, В. И. Слободчикова, Г. И. Челпанова, 
В. Э. Чудновского и др. Немалое значение имеют и труды зарубежных авторов: А. Адлера, А. Маслоу, К. Роджерса, К. Юнга, К. Хорни и др.

Особый вклад в разработку субъектной проблематики был внесен С. Л. Рубинштейном и его учениками - К. А. Абульхановой-Славской и А. В. Брушлинским. Ученый, рассматривая понятие «субъект» Как объяснительный принцип жизни человека, возвел его в статус категории. Введенный им в психологическую науку принцип субъектного подхода требовал учета этической детерминации процессов психического развития. Усилиями учеников С. Л. Рубинштейна проблема субъекта и субъектности была выведена на передний план психологопедагогических исследований. По замыслу А. В. Брушлинского, категория «субъект» должна была выступить основой интеграции психологической науки.

В целом разработка субъектной проблематики велась по двум направлениям: в первом - субъект и субъектность выступали в качестве предмета исследования, во втором - в качестве объяснительного принципа. Первое направление исследований сложилось гораздо раньше второго и во многом явилось его предпосылкой. В качестве предметной области проблема субъекта начала разрабатываться в психологических трудах еще до официального оформления психологии научной дисциплиной ${ }^{1}$. Понятие «субъект» являлось одним из центральных в русской религиозно-философской психологии (В. И. Несмелов, С. Ф. Франк, В. В. Розанов, Л. М. Лопатин и др.). В начале XX в. вопросы, связанные с субъектной проблематикой, поднимались в работах Г. И. Челпанова, И. М. Сеченова, В. М. Бехтерева, М. Я. Басова и др.

В XX столетии прослеживается заметная связь интереса к исследованиям в области субъекта и субъектности с переломными моментами истории, ставящими общество и каждого отдельного человека перед проблемой выбора. Первая волна активных разработок в области субъектной проблематики приходится на $20-30$-е гг., вторая волна - на 80-90-е гг. XX в. Конец XX столетия рассматривается как «период ренессанса» исследований в области субъектной проблематики: она становится «основным научным направлением исследовательской работы Института психологии РАН»².

Разработка субъектной проблематики интенсивно проводилась и в смежных с психологией областях знания. Особое место здесь занимают педагогические и психолого-педагогические исследования. В 80-90-е гг. XX столетия шла активная работа по исследованию условий, способствующих формированию у школьников субъектной позиции, а также - построению концепции субъекта учебной деятельности. Разработка субъектной проблематики в педагогическом аспекте в значительной мере была связана с растущим нежеланием детей учиться. Идея развития у школьников субъектных характеристик виделась эвристичной для решения этой проблемы. Важнейшую роль в формировании такого подхода сыграли работы авторов и разработчиков теории учебной деятельности Д. Б. Эльконина, В. В. Давыдова, В. И. Слободчикова, Г. А. Цукерман и др., связывающие понятие «субъектная позиция школьника» с понятием «субъект

\footnotetext{
${ }^{1}$ Оформление психологии как научной дисциплины произошло в 1879 г.

${ }^{2}$ Психологическая наука в России ХХ столетия / А. В. Брушлинского, ред. М.,1997. С. 346.
} 
Т. П. Войтенко. Принцип субъектного подхода в психологии и педагогике...

учебной деятельности». Нельзя не отметить здесь и исследования Е. Е. Кравцовой, В. Т. Кудрявцева, Т. В. Скляровой, М. Р. Битяновой, Е. Д. Божович и др.

В конце XX - начале XXI в. вокруг субъектной проблематики образовался настоящий «исследовательский бум». Ей посвящалось множество конференций, симпозиумов, монографий. Однако сложилась странная ситуация: результаты исследований в области субъектной проблематики оказались очень противоречивыми и запутанными. Разрывы имели место уже на уровне исходных определений: в различении представлений о субъекте, субъектности и субъективности, в соотношении понятий «субъект» и «личность». Отсутствовало единство мнений и относительно характеристик субъекта: активности, целостности, сознательности, свободы и др.

Противоречивые представления о субъекте выступали серьезным препятствием для использования принципа субъектного подхода. Неразработанность вопроса о связи понятий «субъект» и «личность» затрудняла различение этого принципа с принципом личностного подхода. Дискуссионность вопросов о свободе и активности субъекта не позволяла четко дифференцировать принцип субъектного подхода и принцип активности; нередко отмечалось редуцирование принципа субъекта до принципа активности. В 90-х гг. принцип субъектного подхода был интегрирован с принципом деятельностного подхода в единую методологическую установку - «субъектно-деятельностный подход». Однако методологических трудностей это не устранило.

На наш взгляд, наличие множества противоречий при разработке субъектной проблематики является неслучайным. Причины, порождающие эти противоречия, связаны с особым местом данной проблематики в психологопедагогической науке. Как отмечалось в начале настоящей статьи, разработки ученых в этой области были связаны с представлениями об активной, творческопреобразующей роли человека в мире. С. Л. Рубинштейн, основоположник принципа субъектного подхода, в своих фундаментальных философских трудах «Бытие и сознание» ${ }^{3}$, «Человек и мир» ${ }^{4}$ дал определение субъекта как способ реализации человеком своей человеческой сущности в мире. Другими словами, разработки в области субъектной проблематики настоятельно требуют четкой определенности в антропологическом вопросе. К сожалению, вопрос этот - вплоть до настоящего времени - выступает как «terra incognito», что приводит к огромным трудностям не только в реализации принципа субъектного подхода, но и в понимании его сути. Ярче всего этот момент проявляется в истории развития данного принципа в XX столетии.

\section{К истории проблемы: «Андеграунд диамата»}

Принцип субъектного подхода был введен С. Л. Рубинштейном в психологическую науку в первой четверти XX столетия; датируется это событие выходом в свет его статьи «Принцип творческой самодеятельности» (1922 г., Одесса). По-

${ }^{3}$ Рубинштейн С. Л. Бытие и сознание: о месте психического во всеобщей взаимосвязи явлений материального мира. М., 1957.

${ }^{4}$ Он же. Человек и мир // Проблемы общей психологии. М., 1973. С. 255-285. 
нятие «субъект» С. Л. Рубинштейн рассматривал как объяснительный принцип психической жизни человека и разрабатывал его в русле общепсихологической теории деятельности.

Однако, как свидетельствует историография отечественной психологической науки, в течение нескольких десятилетий ни понятие «субъект», ни принцип субъектного подхода не привлекали внимания психологов. Этот факт кажется удивительным, особенно учитывая то обстоятельство, что категория «деятельность» В это время находилась в центре понятийной системы отечественной психологии.

Объяснение данному факту обычно усматривается в выраженной тенденции того времени к структурно-уровневым исследованиям, что ориентировало ученых на изучение деятельности прежде всего с точки зрения ее состава: компонентов и соотношения между ними; вопрос о субъекте деятельности отходил на задний план.

На передний план вопрос о субъекте деятельности вышел только в 80-90-е гг. XX столетия. Огромную роль в этом сыграли научная деятельность А. В. Брушлинского и его организаторский талант. Работы ученого подтолкнули исследовательскую мысль не только к активным разработкам в области субъектной проблематики, но и к поискам иных объяснений причин ее нахождения «в тени» основного русла психологических исследований в течение более чем полувека. Его статья «Андеграунд диамата» ${ }^{5}$, подготовленная к юбилейной конференции, посвященной памяти С. Л. Рубинштейна, указывала на теснейшую зависимость разработок в области субъектной проблематики от философско-мировоззренческих оснований психологической науки, от ее определенности в антропологическом вопросе.

В XX столетии отечественные ученые пытались построить психологопедагогическую науку на материалистических основаниях. Ценностномировоззренческий уровень всех научных работ определялся «диаматом» (диалектическим материализмом), выступавшим в роли официальной философии. Вопрос об антропологическом контексте психолого-педагогических исследований никогда не становился предметом научных дискуссий. Он - «по умолчанию» - задавался эволюционной концепцией человека через систему соответствующих принципов: причинного детерминизма, структурно-уровневого подхода, развития, активности и др.

Важно заметить, что все методологические установки выводились вовсе не из антропологических представлений - они, как отмечает В. А. Барабанщиков, складывались постепенно и выступали «в качестве итога развития знаний о психике» ${ }^{6}$ Разумеется, лишь тех, которые укладывались в рамки официальной философии. Принцип субъектного подхода - в контексте этой философии оказался в «андеграунде». А его автор, С. Л. Рубинштейн, в 1947-1948 гг. был обвинен в космополитизме и снят со всех постов.

\footnotetext{
${ }^{5}$ Брушлинский А. В. Андеграунд диамата // Проблема субъекта в психологической науке. M., 2000. C. 13

${ }^{6}$ Барабанщиков В. А. Принцип системности и современная психология / Теория и методология психологии: Постнеклассическая перспектива / А. Л. Журавлев, А. В. Юревич, отв. ред. М., 2007. С. 268.
} 
Т. П. Войтенко. Принцип субъектного подхода в психологии и педагогике...

Статья А. В. Брушлинского, написанная в разгар идеологической перестройки 90-х годов, заканчивалась оптимистично: «Теперь мы обрели, наконец, свободу слова, мысли, творчества, совести, так что философия и наука ... уже вышли из подполья» ${ }^{7}$. Перестройка действительно сняла идеологические барьеры в науке. В конце XX столетия, как уже отмечалось, субъектная проблематика вышла на передний план психолого-педагогической науки, стала выступать ее центральной, «узловой» областью исследования.

К сожалению, субъектная проблематика, действительно являясь «узловой точкой» психолого-педагогической науки, оказалась и наиболее «уязвимым местом» ее методологической недоопределенности. Нерешенность антропологического вопроса при разработке данной предметной области оборачивалась методологическим произволом. Уместно процитировать здесь размышления одного из современных авторов, священника В. Леонова: «Большинство ученых каждый сам по себе создает своего “человека” с нуля, и если сопоставить этих “людей”, то получаются несовместимые "существа", почему-то носящие одно и то же имя - “человек". Перед нами предстает "человек” то в виде высокоразвитой обезьяны, то по типу сложноорганизованной системы, то в виде изменчивого объекта, получающего свое оформление в результате различных воздействий социальной среды... Количество версий приближается к числу исследователей...» ${ }^{8}$. Наращивание в таких условиях теоретических моделей не может не приводить к ощущению полного хаоса и методологического тупика. Интерес исследователей к разработке субъектной проблематики уже в первом десятилетии XXI в. стал заметно падать.

В прикладных областях науки кризис субъектной проблематики проявился в особом формате. Противоречивые подходы к пониманию субъекта не позволяли выстроить целостную картину психического развития человека и тем самым лишали твердой опоры педагогическую и психологическую практики. Методологическая недоопределенность психолого-педагогической науки обернулась критическим состоянием развития подрастающих поколений. Как показывают результаты исследований, процессы развития современных детей не укладываются в представления, выработанные наукой предыдущих столетий. «...Ребенок 2010 года... разительно отличается не только от того “дитя”, которого описывали Коменский и Песталоцци, Ушинский и Пирогов, Заззо и Пиаже, Корчак и другие великие детоводители прошлого, он качественно отличается и от ребенка 90-х годов двадцатого столетия», заключает Д. И. Фельдштейн9 .

Сегодня антропологический вопрос стал выходить на передний план психологической науки. Так, В. И. Слободчиков говорит о необходимости введения антропологического принципа в психологическую науку: развивая эту идею, он пишет: «...как будет задано представление о специфике бытия человека... та-

\footnotetext{
${ }^{7}$ Брушлинский. Указ. соч. С. 13.

8 Леонов В., свящ. Антропологический идеал совершенства // Вестник ПСТГУ. Cер. IV: Педагогика. Психология. 2006. Вып. 2. С. 81-92.

${ }_{9}^{9}$ Фельдштейн Д. И. Психолого-педагогические проблемы построения новой школы в условиях значимых изменений ребенка и ситуации его развития // Проблемы современного образования. 2010. № 2. С. 7.
} 
кую интерпретацию частных понятий о его конкретном бытии мы обретем» ${ }^{10}$. Нельзя не отметить здесь и В. А. Барабанщикова, утверждающего: «Очевидно, что в психологии то или иное понимание человека - "альфа" и “омега" любых конкретных исследований» ${ }^{11}$. Созвучные представления встречаются в работах многих авторов.

Однако далеко не всякий антропологический контекст является продуктивным для психолого-педагогических исследований. На наш взгляд, А. В. Брушлинский очень метко назвал субъектную проблематику «андеграундом» диамата: эволюционная концепция человека (на которую была вынуждена опираться вся отечественная психология советского периода) «запирала» эту проблематику «в подполье».

В каком антропологическом контексте должны разрабатываться и раскрываться понятие «субъект» и принцип субъектного подхода? Для ответа на этот вопрос видится необходимым подойти к обсуждаемой проблеме в более широком ракурсе: за сравнительно короткой историей принципа субъектного подхода в психолого-педагогической науке стоит очень долгая предыстория понятия «субъект» в философской мысли, скрывающая в себе диалектику представлений человека о своем месте и роли в окружающем мире.

\section{К предыстории проблемы: диалектика понятия «субъект» в философии}

Понятие «субъект» возникло в самом начале философской мысли. Пройдя через всю ее историю, оно много раз меняло смыслы. Некоторые из них утрачивались и возвращались вновь, другие возникали и развивались как антитеза исходным.

В этих метаморфозах вряд ли следует усматривать что-либо исключительное: диалектическое состояние понятий считается одним из самых важных открытий Г-В. Ф. Гегеля. Комментируя это открытие, глубокий философ и исследователь творчества Гегеля И. А. Ильин писал: «Пнятию как таковому свойственна некая внутренняя диалектика: ему свойственно становиться во "внутреннее противоречие” с самим собою, разделяться на новые понятия, исключающие друг друга... Диалектика понятий, порождающая, по словам Гегеля, ощущение “гибнущего разум", отражает подлинное - диалектическое - состояние самого предмета и потому не только не отзывается гибельно на познании и философии, но, наоборот, служит их утверждению и расцвету» ${ }^{12}$.

Наиболее полный анализ понятия «субъект» в философии принадлежит М. Хайдеггеру. Опираясь на работы этого автора, и попробуем показать его диалектику. При этом сделаем у М. Хайдеггера еще одно заимствование: установку

${ }^{10}$ Слободчиков В. И. Очерки психологии образования. Биробиджан, 2005. С. 81.

${ }^{11}$ Барабанщиков В. А. С. Л. Рубинштейн и Б. Ф. Ломов: преемственность научных традиций // Проблема субъекта в психологической науке. М., 2000. С. 44.

${ }^{12}$ Ильин И. А. Философия Гегеля как учение о конкретности Бога и человека. В 2 т. СПб., 1994. T. 1. C. 112. 
Т. П. Войтенко. Принцип субъектного подхода в психологии и педагогике...

на «хождение путями, намеченными языком». «Только через потаенное существо слова мы раскрываем сущность вещей» - говорил автор ${ }^{13}$.

Согласно М. Хайдеггеру, субъект, subject(um) - это латинский перевод и ис-

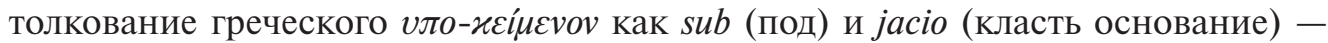
означает буквально «положенное-под-основу» ${ }^{14}$. В соответствии с каждой из трех частей перевода можно выделить три смысловых акцента в значении слова $\operatorname{subject(um):}$

• сущностности, принципиальности («положенное-под-основу»);

- потаенности, неизвестности, не-явности («положенное-под-основу»);

- несамодостаточности, под-ответности («положенное-под-основу» [кем-то]).

Заметим, что все три значения слова subject сохранены в современном английском языке ${ }^{15}$. Что касается истории, то в разные эпохи происходило акцентирование разных смысловых частей слова subject(um).

В эпоху античности дефиниция «субъект» имела в основном значение потаенного. Понятие носило метафизико-онтологический характер.

Античная философия, искавшая ответ на вопрос: «Что есть сущее (бытие)?», различала в бытии круги явленного (физического) и потаенного (того, что за физическим - meta ta physika - но составляет основу сущего). Последнее и рассматривалось как субъект, subjectum.

Потаенная основа виделась во всех вещах - все они и мыслились как субъекты. Камни, растения, звери в период античной философии рассматривались как субъекты ничуть не в меньшей мере, чем люди. Говоря об истоках обсуждаемой дефиниции, М. Хайдеггер специально обращает внимание на то, что первоначальное метафизическое значение понятия «субъект» не имело «никакого подчеркнутого отношения к человеку» ${ }^{16}$. Субъект скрывался во всем многообразии вещей; противоположное субъекту - объект - обладал свойствами единичности и исключительности.

Именование субъектами всех вещей сохраняется также в ранние Средние века. В период мощного распространения и утверждения христианства, когда оно, по выражению М. Хайдеггера, являлось «силой, образующей историю» ${ }^{17}-$ все метафизические размышления исходили из христианских догматов. Особенно большое значение для философской мысли этого времени (получившего название «периода схоластики» - от лат. schola) имели труды греческих и латинских отцов Церкви: Леонтия Византийского, Максима Исповедника, Дионисия Ареопагита, Иоанна Дамаскина, Августина Блаженного и др.

${ }^{13}$ Хайдеггер М. Время и бытие. М., 1993. С. 311.

${ }^{14}$ Там же. С. 118.

${ }^{15}$ В Англо-русском словаре (В. К. Мюллер, сост. 1969. С. 751) приводятся следующие значения слова subject:

- subject - грам. подлежащее (лежащее-в-основе (главный член) предложения), муз. главная тема;

- subject matter - предмет изучения (неизвестный для изучающего. $-T$. B.)

- subject nations - несамостоятельные государства.

${ }^{16}$ Хайдеггер. Указ соч. С. 48.

${ }^{17}$ Там же. С. 119. 
Христианское учение, как пишет М. Хайдеггер, сняло с понятия subject «покров потаенности», дав однозначный ответ на вопрос о том, что лежит в основе сущего: «Бытие сущего заключается в его сотворенности Богом, всякое сущее есть сотворенное сущее» ${ }^{18}$.

Античная философия не знала идеи творения. В философской мысли ранних Средних веков эта идея занимает центральное место. Христианский догмат о тварности является узловым для понимания принципа субъекта. Из него вытекают два важнейших для нас момента:

- о бытии как творении;

- о тварном как призванном.

Для осмысления этих моментов обратимся к богословским работам В. Н. Лосского, оставив на некоторое время в стороне М. Хайдеггера. В. Н. Лосский, ссылаясь на труды Максима Исповедника, Иоанна Дамаскина, Дионисия Ареопагита, Григория Нисского и других отцов Церкви, раскрывает основу христианского мировоззрения следующим образом: тварные вещи не существуют без (вне) Творца, ничего не существует вне Бога ${ }^{19}$.

По учению прп. Иоанна Дамаскина, каждая вещь получала бытие свое в определенное время согласно Божественной мысли-волению, которая есть «предопределение» и «образ». Идеи-воления не тождественны вещам тварным - они отделены от тварного, как воля художника отделена от произведения, в котором она проявляется ${ }^{20}$. Но идеи-воления Творца и присутствуют в бытии каждой сотворенной вещи - как художник присутствует в каждом своем произведении. Другими словами, понимание бытия как творения выводит нас к идее бытия как со-бытия.

Божественные логосы-воления - это не человеческие слова, «которые кончаются и исчезают, как только сходят с уст: Его слова исходят, но не приходят»пишет В. Н. Лосский ${ }^{21}$. Ссылаясь на учение свт. Григория Нисского, автор называет слово Божье «светозарной силой», которая пронизывает все тварное бытие и удерживает его 22.

Все тварное существует во времени, находится в изменении, движении. Движение тварного, по учению прп. Максима Исповедника, раскрывает его бытие как бытие во времени и пространстве. В отличие от Творца, который «Один... остается в абсолютном покое, и совершенная Его неподвижность ставит Его вне времени и пространства» ${ }^{23}$.

Движение тварного - задано призванностью. Божественные логосыволения, которые есть «предопределения» и «предвидения» - это призванность не только из не-бытия к бытию, но и к определенному «качеству» бытия. Первозданное состояние тварного не есть его конечная цель; цель тварного - вне его: в движении к Богу и соединении с ним (в обожении).

${ }^{18}$ Хайдеггер. Указ соч. С. 113.

${ }^{19}$ Лосский В. Н. Очерк мистического богословия Восточной Церкви. Догматическое богословие. М., 1991. С. 71.

${ }^{20}$ Там же. С. 74.

${ }^{21}$ Там же. С. 82.

${ }^{22}$ Там же.

${ }^{23}$ Там же. С. 75. 
Т. П. Войтенко. Принцип субъектного подхода в психологии и педагогике...

В этом Целе-направленном движении всего тварного особая роль отводится человеку. В христианском учении человек понимается не только как венец Божественного плана мироустройства, но, по выражению В. Н. Лосского, «как самый его принцип». Обожение тварного мира достигается через свободную волю человека, его сознательное Бого-уподобление. В этом и состоит Высшее призвание человека. В силу единоприродности всех тварных вещей обожение человека приводит к обожению всего мира ${ }^{24}$.

...Вернемся к М. Хайдеггеру. В философской мысли периода христианства на первое место в дефиниции «субъект» выходило значение под-ответности. Все тварные вещи бытийствуют как ответственные Богу; при этом человек не только является частью общего субъекта, но несет и личную ответственность. Формула христианского мышления: «Без Объекта нет субъекта».

В философии Нового времени произошло кардинальное изменение понятия «субъект». М. Хайдеггер пишет, что оно утратило свойство всеобщности и стало мыслиться как единичное и исключительное; этим единственным и исключительным субъектом стал человек ${ }^{25}$.

Трансформации понятия «субъект» были связаны с начавшимся с конца XIII в. в Западной Европе процессом секуляризации философии. Путь Откровения, понимавшийся в ранние Средние века как единственно возможный путь истины, оказался «по ту сторону» философии. Человек стал искать истину, опираясь на им самим найденное, на доказательность.

Философия Нового времени берет свое начало от работ Р. Декарта, давшего образ человека, мыслящего по-новому (картезианского человека) ${ }^{26}$. Основной метафизический вопрос - что есть бытие? - такой человек решает, опираясь на самого себя: «Ego cogito, ergo sum». Этим известным тезисом - «Я мыслю, следовательно, я существую» - вопрос о бытии переносится в сферу сознания человека.

Нахождением нового способа определения сущности бытия - через человека, его $Я$ - заново решается положение о sub-jectum. «В области господства этого субъекта сущее - уже не сотворенное сущее, оно - представленное сознанию сущее», - пишет М. Хайдеггер и заключает: для нового мышления лежащим-воснове, subjectum становится самость человека ${ }^{27}$.

Если проанализировать картезианскую метаморфозу понятия «субъект» с точки зрения смысловых акцентов, то мы видим, что произошло отрицание третьего смыслового акцента - «положенного-под-основу» как несамодостаточного - и развитие его антитезы. А именно: субъект (человек) стал пониматься как существо самодостаточное.

Что же стало со всеми другими вещами, по отношению к которым раньше наравне с человеком - могла быть использована дефиниция «субъект»? Утратив возможность мыслиться как «субъекты», они превратились в объекты. Объект -

${ }^{24}$ Лосский. Указ. соч. С. 239.

${ }^{25}$ Хайдеггер. Указ соч. С. 131.

${ }^{26}$ Декарт Р. Рассуждения о методе. Метафизические размышления о новой философии // Избранные произведения. М., 1950.

${ }^{27}$ Хайдеггер. Указ соч. С. 125-131. 
как Высшая и единственная Цель - новоевропейским мышлением раздробился на множество объектов-вещей.

Метафизико-онтологический ракурс философии сместился на гносеологический. Вместо вопроса «о бытии сущего» человек стал строить «картины мира». Сущее превратилось в объекты-предметы познания, противостоящие познающему их субъекту. На место формулы: «Без объекта нет субъекта» встала иная «Без субъекта нет объекта» ${ }^{28}$.

Новое мышление человека открыло новую эпоху в истории человечества и сделало последующее время Новым временем. Значение этого переворота в мышлении человека на протяжении всей последующей истории оценивалось исключительно позитивно. Приведем выдержку из недавнего энциклопедического издания: «Вся современная наука и техника возникла благодаря тому, что Декарт поставил людей по отношению к природе на такую позицию, с которой только вообще и открываются возможности полного завоевания природы. Декарт научил людей думать так, что они смогли создать технику ${ }^{29}$. Лишь немногими мыслителями новое мышление человека рассматривалось как тупиковое, как начало трагедии человеческой истории.

Одним из таких мыслителей являлся и М. Хайдеггер. Новое мышление, говорил автор, превратило человека в «существо, ограниченное своей прихотью и отпущенное на собственный произвол» ${ }^{30}$. Человек с технократическим мышлением не задается онтологическими вопросами, не ощущает своего единства с миром. Он перекраивает мир на свой лад. «Картина мира» сменяется «техническим проектом». Словом «техника» М. Хайдеггер обозначает не только «области машинного производства и технического вооружения», но и «опредмеченную природу, устроенную культуру, подстроенную политику, надстроенные идеалы» ${ }^{31}$.

...Возвращение онтологического статуса понятию «субъект», равно как и поворот философской мысли к христианскому учению, начался с работ И. Г. Фихте. Идеи Фихте нашли свою преемственность в философии Ф. Шеллинга, а затем - и Г-В. Ф. Гегеля. Учение Гегеля рассматривается как кульминационный момент в истории философской мысли. От него берут свое начало все современные философские течения. Для нашей работы это учение имеет принципиальное значение: именно в нем содержатся истоки отечественных разработок субъектной проблематики, заложенные С. Л. Рубинштейном. Поэтому остановимся на этом учении чуть подробнее, обратившись к первоисточникам, а также к трудам И. А. Ильина, глубочайшего исследователя творчества Гегеля.

Понятие субъекта в философской системе Гегеля представлено очень широко и многопланово. Проведя анализ всех работ философа, И. А. Ильин дал следующее обобщающее определение гегелевского субъекта: «Субъект есть начало творческого беспокойства: он “движет себя”, относится к себе негативно и

\footnotetext{
${ }^{28}$ Хайдеггер. Указ соч. С. 177-192.

${ }^{29}$ Краткая философская энциклопедия / Е. Ф. Губский, ред.-сост. М., 1994.

${ }^{30}$ Хайдеггер. Указ. соч. С. 49-50.

${ }^{31}$ Там же. С. 182.
} 
Т. П. Войтенко. Принцип субъектного подхода в психологии и педагогике...

создает себя в этой рефлексии; он живет в себе, и жизнь его есть его “собственная деятельность”; он совершает в себе диалектический процесс; вызывает в себе противоречия и тем углубляется в себя. Этим он сообщает себе "самостную форму”, форму творческой, бесконечной самостоятельности, и в то же время “уверенной в себе” конкретной единичности» ${ }^{32}$.

Понять данное определение субъекта невозможно вне фундаментальных идей философской системы Гегеля, которая, по мысли И. А. Ильина, показывает «путь Бога (Божественного Логоса) в мире» ${ }^{33}$. Два этапа пути Божественного Логоса - нисходящий и восходящий - диалектически сопряжены, и именно через них выводятся гегелевские понятия «субъекта» и «субъективности» ${ }^{34}$.

Нисходящий этап представляет собой отчуждение Божественного Логоса в природу; это первое отрицание, первое ино-бытие Абсолюта. Будучи чистой логической сущностью, имеющей моменты всеобщности, особенности и единичности, Божественный Логос, соответственно, отчуждается в природу: как инобытие вообще (в форме пространства и времени), как инобытие в форме определенной особенности (неживая природа) и как инобытие в форме конкретной единичной индивидуальности (живая природа) ${ }^{35}$.

На последней ступени природы - конкретной живой индивидуальности Божественный Логос отчуждается как субъективность. Инобытие Божественного Логоса в форме субъективности также имеет три ступени: растительная природа - животная природа - человек. В растительной природе субъективное начало не до конца еще оформлено; животное обладает субъективным началом в форме самоощущения, самочувствия. На последней ступени - в бытии человека - субъективность обретает форму сознания.

Восходящий этап пути Божественного Логоса - это второе его инобытие, представляющее собой отрицание первого. Второе инобытие Божественного Логоса снимается как субъект, проявляющий себя в форме духа. Проявление духа в полной мере возможно лишь при наличии сознания. Поэтому полным субъектом является только человек. На ступенях растительной и животной природы дух не проявляется в полной мере; растения и животные являются неполными субъектами ${ }^{36}$.

Гегель показывает диалектическую связь понятий «субъект» и «субъективное»: субъект - это снятое субъективное. Отношения субъекта и объекта также диалектичны. Диалектика ярче всего проявляется в процессе познания: через познание человек открывает диалектику вещей и, таким образом, усваивает метод мышления. Гегель многократно говорит о том, что диалектика - это прежде всего объективный ритм предмета, и уже потом - метод познания ${ }^{37}$.

В процессе познания устанавливается метафизико-онтологическое тождество субъекта и объекта ${ }^{38}$. Эта идея занимает центральное место в философской

${ }^{32}$ Ильин. Указ. соч. С. 164.

${ }^{33}$ Там же. С. 161.

${ }^{34}$ Там же. С. 161-254.

${ }^{35}$ Гегель Г. В-Ф. Наука логики. Книга первая. Учение о бытии. М., 1970.

${ }^{36}$ Он же. Энциклопедия философских наук. Т. 3. Философия духа. М., 1977.

${ }^{37}$ Гегель. Наука логики... С. 295-335.

${ }^{38}$ Он же. Энциклопедия философских наук... 
системе Гегеля. Понятие субъект в ней представлено - в первую очередь - как онтологическое, причастное Абсолюту; нечто, лишенное такой причастности, по Гегелю, лишено бытия вообще, является фантомом, иллюзией. Через призму этой центральной идеи и раскрывается гегелевское определение субъекта.

Завершая рассмотрение понятия «субъект» в философии, нельзя не обратиться еще к двум философским течениям XX столетия, оказавшим значительное влияние на «судьбу» этого понятия в психологической науке и развивавшимся в непосредственной связи с философской системой Гегеля: диалектическому материализму и экзистенциализму.

Экзистенциализм продолжил линию онтологических вопросов и поиска ответов на них с позиции христианского учения. Бытие субъекта (subjectum, лежащего-в-основании) понимается в экзистенциализме как ответность творящей Первопричине ${ }^{39}$. Смысл бытия раскрывается через смерть - пограничную ситуацию - дающую существованию возможность понять себя как целое.

Философия экзистенциализма оказала заметное влияние на развитие зарубежной психологии. Она не только привела к возникновению нового направления психологической мысли - экзистенциальной психологии (В. Франкл, Э. Фромм), но ее влияние угадывается и в работах создателей гуманистического направления в психологии и педагогике (А. Маслоу, К. Роджерс), а также - «отступников» психоанализа (К. Юнг, К. Хорни, А. Адлер, Г. Олпорт). По мнению Л. И. Анциферовой, в теориях многих зарубежных психологов XX столетия «понятие "субъект" занимает одно из центральных мест», обозначая способность человека «быть инициирующим началом... творцом своей жизни...» ${ }^{40}$.

Развитие отечественной психолого-педагогической науки напрямую связано с другим философским течением - «диаматом», основоположниками которого являлись К. Маркс, Ф. Энгельс, В. И. Ленин.

Ф. Энгельс попытался дать материалистическую трактовку диалектике Гегеля. Это привело к еще одному изменению понятия «субъект»: оно стало связываться, в первую очередь, с практикой, деятельностью. К. Маркс, следуя идеям немецкой классической философии, также подчиняет человеческого субъекта более высокой сущности, но в качестве таковой у него выступает не Абсолют, а общество. Согласно марксизму индивид является субъектом настолько, насколько он овладевает орудиями общественной, предметно-практической деятельности.

Гносеология диамата также связывается с практикой: практика выступает здесь как основной стимул и цель познания. Редукция познания со стороны цели (в пределе доводящая познавательный прагматизм до вульгарного) усугубляется редукцией со стороны процесса: процесс познания, согласно теории В. И. Ленина, понимается как процесс отражения.

Являясь государственной философией нашей страны на протяжении $\mathrm{XX}$ столетия, диамат выступал методологической основой всей отечественной

\footnotetext{
${ }^{39}$ Хайдеггер. Указ. соч. С. 49-50.

${ }^{40}$ Анциферова Л. И. Психологическое содержание феномена субъект и границы субъектнодеятельностного подхода // Проблема субъекта в психологической науке. М., 2000. С. 29-30.
} 
Т. П. Войтенко. Принцип субъектного подхода в психологии и педагогике...

науки. Понятие «субъект» и принцип субъектного подхода оказались в ней в «андеграунде».

Христианское учение о человеке - «родное лоно» понятия «субъект». Именно в контексте христианской антропологии должно разрабатываться и раскрываться его содержание.

\section{Субъектный подход в контексте христианских представлений о человеке}

В завершение настоящей статьи попробуем систематизировать христианские антропологические представления, чтобы логически вывести из них содержание понятия «субъект» и принцип субъектного подхода.

Систему христианских представлений о человеке представим в тезисной форме.

1. Человек - существо, сотворенное Богом. Тварное начало объединяет человека со всем миром, сообщает ему онтологические характеристики, свойственные всем тварным сущностям. Все тварное существует как противоположное Творцу и - одновременно - как [неразрывно] связанное с Ним: бытие тварного - есть со-бытие.

2. Человек - существо, сотворенное как целевая детерминанта мироздания и призванное привести к Богу (к обожению) весь тварный мир. Человек - существо, наделенное свободой воли (само-действующее); деяния человека определяют не только его судьбу, но и судьбу всего мироздания. За свои деяния человек ответствует перед Богом.

3. Человек - существо, сотворенное по образу Божьему. Основное выражение образа Божьего в человеке - это начало личности. Личностное начало есть только у человека. Никакое другое живое существо не обладает личностным началом - ни одно из них не призвано к [личному] ответу.

4. Обладая уникальным личностным началом, люди не являются отъединенными друг от друга единицами, они связаны невидимыми духовными связями, образуя единосущие. Человек - существо соборное, сотворенное по образу соборности (Единства Трех Личностей) Божества: «Сотворим человека по образу Нашему и по подобию Нашему» (см. Быт 1. 26). Не единичен Творец, не единичен и человек, сотворенный по Его образу. Человек ответствует перед Богом не только как существо личное, но и как существо соборное.

5. [Современный] человек - существо падшее. В силу соборности, духовного всеединства людей, возможно всеобщее падение и всеобщее восстановление через действие воли отдельного человека: «Как преступлением одного всем человекам осуждение, так и правдою одного всем человекам оправдание» (см. Рим 5. 18).

Грехопадение Адама изменило онтологические характеристики человека. Разорвались духовные связи человека с Богом, разрушилась соборность человеческой сущности. Опрокинулась вся изначальная иерархия человеческого устроения: дух, разорвав свою благодатную связь с Богом, попал в зависимость от души, душа поработилась телом. Свобода воли оказалась связанной грехом, 
образовался сильнейший разлад: «Плоть желает противного духу, а дух - противного плоти, и оба они друг другу противятся» (см. Гал 5. 17). Повредилось личностное начало человека. В. Н. Лосский характеризует человеческую личность как слепую и бессильную ${ }^{41}$. В. В. Зеньковский также пишет: «Начало личности в нас неполно и ограничено» ${ }^{42}$ В бытие человека вошли болезни, скорби, смерть: препятствия разрушительному действию поврежденной грехом свободной человеческой воли. Однако грех - не бесконечен, он имеет нравственный предел: смерть. «Бог вносит во избежание полного распада под действием зла некий порядок в самую гущу беспорядка. Его благая воля устрояет и охраняет вселенную... Для человека лучше смерть...чем закрепление в вечности его чудовищного положения», - пишет В. Н. Лосский ${ }^{43}$.

6. [Современный] человек - существо, искупленное Божьей любовью: Боговоплощением и крестной жертвой Иисуса Христа.

В разорванных духовных связях, силою поврежденной грехом воли, человек оказался не в состоянии осуществить свое предназначение: ответить на Призвание и, достигнув Богоподобия, привести к обожению все мироздание. Спасая Свое творение, Бог нисходит к человеку.

Жертва Христа, обновив природу человека, открыла новый путь к Богу, как бы «обходной»: через любовь к ближнему ${ }^{44}$. Путь показан личным примером: «Я есть путь» (см. Ин 14. 6), «Следуйте за мной» (см. Мф 9. 9), - говорил Христос.

Жертва Христа просветила Божьей любовью все мироздание - человеку было заповедано стать ее рачительным восприемником. Выполнение человеком своего предназначения обрело характер подответного долга ${ }^{45}$.

7. Осуществить свое призвание [современный] человек может только в соработничестве с Богом. «Человек был сотворен одной волей Божьей, но ею одной он не может быть обожен. Одна воля в творении, но две - в обожении. Одна воля для создания образа, но две - для того, чтобы образ стал подобием», - говорит В. Н. Лосский ${ }^{46}$.

В контексте изложенных антропологических представлений, возвращая понятию «субъект» (subject(um)) его исходное метафизико-онтологическое значение ${ }^{47}$ и ассимилируя представления, устоявшиеся в психологической науке, дадим определения субъекта, субъектности и субъективности, а также - формулировку принципа субвектного подхода.

Субъект - динамичная (находящаяся в состоянии активности) тварная сущность, подответная Творцу.

${ }^{41}$ Лосский. Указ. соч. С. 95

42 Зеньковский В. В. прот. Проблемы воспитания в свете христианской антропологии. Клин, 2002. С. 65.

${ }^{43}$ Там же. С. 253

${ }^{44} \mathrm{O}$ данных людям новых заповедях: «Возлюби Господа Бога твоего...» и «Возлюби ближнего твоего...» Христос говорил как о подобных (см. Мф 22. 37-40; Мк 12. 29-31).

${ }^{45}$ Притча о талантах (см. Мф 25. 14-30).

${ }^{46}$ Лосский. Указ. соч. С. 244.

${ }^{47}$ Как «положенного-под-основу» - в единстве всех трех смысловых акцентов: сущностности, потаенности, подответности. 
Т. П. Войтенко. Принцип субъектного подхода в психологии и педагогике...

Суббектность - универсальная характеристика бытия, присущая материи на всех ее уровнях; при этом на каждом из уровней имеющая свои специфические особенности.

Общими характеристиками субъектности, свойственными всем уровням, являются: противоположность Объекту (как конечной Цели) и активность (целеустремленность, Движение).

На уровне разумного бытия (человека) субъектность раскрывается совершенно особым, исключительным образом: субъект вначале проявляется как субъективность, а затем - в процессе нормативного развития - субъективность преобразуется в осознанную субъектность (В. И. Слободчиков), а затем снимается личностью. Субъектность выступает не только как характеристика бытия, но и становится характеристикой сознания.

На уровне разумного бытия субъектность проявляется как развивающееся образование, восходящее к осознанию человеком своей глубочайшей (потаенной) связанности со всеми людьми и миром в целом, сочетающейся со свободой личного выбора и ответственностью «за все содеянное и упущенное» (С. Л. Рубинштейн). На уровне разумного бытия субъектность имеет два формата: коллективный и индивидуальный. Человек - как коллективный и индивидуальный субъект - занимает определенную (субъектную) позицию по отношению к себе и окружающему миру, позиция проявляется в деятельности.

Принцип суббектного подхода как объяснительный принцип психической жизни человека требует рассматривать в качестве ведущей детерминанты психического антропо-этический фактор: свободную волю человека, направляющую его деятельность. Это - гносеологический аспект принципа. В онтологическом аспекте этот принцип раскрывается как заповедь, данная человеку Божественным Откровением еще в Ветхозаветные времена:

«Во всех делах твоих помни о конце твоем...» (см. Сир 7. 39).

Ключевые слова: принцип субъектного подхода, методологический кризис, диалектика понятия «субъект», антропологический контекст понятия «субъект», христианскоправославная антропология, свобода воли.

\section{Список литературы}

Анциферова Л. И. Психологическое содержание феномена субъект и границы субъектнодеятельностного подхода // Проблема субъекта в психологической науке. М., 2000. C. $27-42$.

Барабанщиков В. А. Принцип системности и современная психология / Теория и методология психологии: Постнеклассическая перспектива / А. Л. Журавлев, А. В. Юревич, отв. ред. М., 2007. С. 268-286.

Барабанщиков B. A. С. Л. Рубинштейн и Б. Ф. Ломов: преемственность научных традиций // Проблема субъекта в психологической науке. М., 2000. С. 43-52.

Брушлинский A. B. Андеграунд диамата // Проблема субъекта в психологической науке. М., 2000. C. 7-13.

Гегель Г. В-Ф. Наука логики. Книга первая. Учение о бытии. М., 1970.

Гегель Г. В-Ф. Энциклопедия философских наук. Т. 3. Философия духа. М., 1977. 
Декарт Р. Рассуждения о методе. Метафизические размышления о новой философии // Избранные произведения. М., 1950.

Зеньковский B. B., прот. Проблемы воспитания в свете христианской антропологии. Клин, 2002.

Ильин И. А. Философия Гегеля как учение о конкретности Бога и человека. В 2 т. СПб. 1994. Т. 1.

Краткая философская энциклопедия / Е. Ф. Губский, ред.-сост. М., 1994.

Леонов B., свящ. Антропологический идеал совершенства // Вестник ПСТГУ. Cер. IV: Педагогика. Психология. 2006. Вып. 2. С. 81-92.

Лосский В. Н. Очерк мистического богословия Восточной Церкви. Догматическое богословие. М., 1991.

Психологическая наука в России XX столетия / А. В. Брушлинского, ред. М.,1997. C. 346.

Рубинштейн С. Л. Человек и мир // Проблемы общей психологии. М., 1973. С. 255-285.

Рубинштейн С. Л. Бытие и сознание: о месте психического во всеобшей взаимосвязи явлений материального мира. М., 1957.

Слободчиков В. И. Очерки психологии образования. Биробиджан, 2005.

Фельдштейн Д. И. Психолого-педагогические проблемы построения новой школы в условиях значимых изменений ребенка и ситуации его развития // Проблемы современного образования. 2010. № 2. С. 5-12.

Хайдеггер М. Время и бытие. М., 1993.

\section{A Principle of Subjective Approach in Psychology and Pedagogy: The Problem of Anthropological Context}

\section{T. VOITENKO}

The paper discusses problems of implementing the principle of subject approach and its complicated history in science. The reasons for these complications are considered to be the anthropological vagueness of studies dealing with the notion of subject. It is argued that not every anthropological context of the notion of "subject" is productive. The evolutionary conception of man, on which Russian science of the Soviet period had to be established, was a serious obstacle for research of subject and subjectivity. The paper puts forward the idea that a huge potential of the principle of subjective approach, which is the basic methodological dominance of modern psychology and pedagogy, can only be employed in the context of Orthodox Christian anthropology. The paper provides historiographical and methodological evidence for this point of view. The history and prehistory of the principle of subjective approach are traced together with 
Т. П. Войтенко. Принцип субъектного подхода в психологии и педагогике...

the dialectics of the concept "subject" in philosophical thought. The author systematises the Orthodox Christian view of man and, based on this, gives definitions of the terms "subject", "subjectivity" and "subjectiveness". These definitions are in line with the theories of subject developed by S. Rubinshtein and V. Slobodchikov.

Keywords: principle of subjective approach, methodological crisis, dialectics of "subject", anthropological context of "subject", Orthodox Christian anthropology

\section{References}

Anciferova L. I., Psihologicheskoe soderzhanie fenomena sub"ekt $i$ granicy sub"ektnodeyatel'nostnogo podhoda, in: Problema sub"ekta $v$ psihologicheskoj nauke, Moscow, 2000, 27-42.

Barabanshchikov V. A., Princip sistemnosti $i$ sovremennaya psihologiya, in: Teoriya i metodologiya psihologii: Postneklassicheskaya perspektiva, A. L. Zhuravlev, A. V. Iurevich, eds., Moscow, 2007, 268-286.

Barabanshchikov V. A., Rubinshtejn i B. F. Lomov: preemstvennost' nauchnyh tradicij, in: Problema sub"ekta $v$ psihologicheskoj nauke, Moscow, 2000, 43-52.

Brushlinskij A. V., Andegraund diamata, in: Problema sub"ekta $v$ psihologicheskoj nauke, Moscow, 2000, 7-13.

Dekart R., Rassuzhdeniya o metode. Metafizicheskie razmyshleniya o novoj filosofii, in: Izbrannye proizvedeniya, Moscow, 1950.

Fel'dshtejn D. I., Psihologo-pedagogicheskie problemy postroeniya novoj shkoly $v$ usloviyah znachimyh izmenenij rebenka $i$ situacii ego razvitiya, in: Problemy sovremennogo obrazovaniya, 2010, № 2, 5-12.

Gegel' G. V-F., Nauka logiki. Kniga pervaya. Uchenie o bytii, Moscow, 1970.
Gegel' G. V-F., Ehnciklopediya filosofskih nauk. T. 3. Filosofiya duha, Moscow, 1977.

Hajdegger M., Vremya i bytie, Moscow, 1993.

Il'in I. A., Filosofiya Gegelya kak uchenie o konkretnosti Boga i cheloveka. V 2 t., St. Petersburg, 1994, T. 1.

Kratkaya filosofskaya ehnciklopediya, E. F. Gubskij, ed., Moscow, 1994.

Leonov V., svyashch. Antropologicheskij ideal sovershenstva, in: Vestnik PSTGU. Ser. IV: Pedagogika. Psihologiya, 2006, Vyp. 2, 8192.

Losskij V. N., Ocherk misticheskogo bogosloviya Vostochnoj Cerkvi. Dogmaticheskoe bogoslovie, Moscow, 1991.

Psihologicheskaya nauka v Rossii XX stoletiya / A. V. Brushlinskogo, ed., Moscow, 1997, 346.

Rubinshtejn S. L., Chelovek i mir, in: Problemy obshchej psihologii, Moscow, 1973, 255285.

Rubinshtejn S. L., Bytie $i$ soznanie: o meste psihicheskogo vo vseobshchej vzaimosvyazi yavlenij material'nogo mira, Moscow, 1957.

Slobodchikov V. I., Ocherki psihologii obrazovaniya, Birobidzhan, 2005.

Zen'kovskij V. V., prot. Problemy vospitaniya v svete hristianskoj antropologii, Klin, 2002. 